\title{
Improve the quality of counseling for HIV in the district of Guédiawaye
}

\author{
Sakho D Maty ${ }^{*}$, Seck Karim, Ouattara Baly, Gaye Alioune, Sylla Bintou \\ From 17th International Symposium on HIV and Emerging Infectious Diseases (ISHEID) \\ Marseille, France. 23-25 May 2012
}

\section{Objectives}

HIV counseling and testing for several years working in the district of Guédiawaye. A situation analysis has revealed shortcomings in the organization of the service given the many other activities of the health center. This is why the medical team decided to use the collaborative model of quality improvement that is based on the implementation of a package of changes and the measurement of indicators of improvement.

\section{Methodology}

It consisted of a situational analysis of the Board Search, the development of process maps and identify targets for improvement. Improvement targets were selected to make the results of all HIV tests to clients within two hours, to provide the reference of all patients positive for medical care. The changes have been to extend the opening hours of the laboratory, to assign a specific staff for testing and to ensure continuous availability of a pool of consultants. Better communication was established and the customer's circuit has been reduced.

\section{Results}

From January to December 2010, the proportion of tests performed in two hours has risen by an average of $35 \%$ to $99 \%$, also the proportion of patients actually referred for medical care rose from an average of $33 \%$ to $97 \%$.

\section{Conclusions and recommendations}

The process of improving not only affects the indicators of improvement but the effects on teamwork and a consideration of the basic needs of patients.

* Correspondence: sakhomaty@gmail.com

Médecin Spécialiste du Vih at District Sanitaire de Guédiawaye Synergie pour I'Enfance, Dakar, Senegal
Published: 25 May 2012

doi:10.1186/1742-4690-9-S1-P86

Cite this article as: Maty et al.: Improve the quality of counseling for HIV in the district of Guédiawaye. Retrovirology 2012 9(Suppl 1):P86.
Submit your next manuscript to BioMed Central and take full advantage of:

- Convenient online submission

- Thorough peer review

- No space constraints or color figure charges

- Immediate publication on acceptance

- Inclusion in PubMed, CAS, Scopus and Google Scholar

- Research which is freely available for redistribution
() Biomed Central
C Biomed Central

(c) 2012 Maty et al; licensee BioMed Central Ltd. This is an Open Access article distributed under the terms of the Creative Commons Attribution License (http://creativecommons.org/licenses/by/2.0), which permits unrestricted use, distribution, and reproduction in any medium, provided the original work is properly cited. 